\title{
The Development of Flipped Learning Model Based on MyBrilian to Support Planned Online Learning
}

\author{
M. J. Dewiyani Sunarto \\ Department of Information System, Faculty of Technology and Informatics, Universitas Dinamika, \\ Surabaya, Indonesia \\ Corresponding author email: dewiyani@dinamika.ac.id
}

Received: 07 February 2021; Revised: 28 February 2021; Published: 30 March 2021

\begin{abstract}
The Covid 19 pandemic period has changed the learning system, including the presence of online learning. Literature reviews from various sources state that the Flipped Learning model is an alternative model for an online learning. Even so, the Flipped Learning model cannot be implemented directly. It must be adapted to the conditions where students learn. The development of the Flipped Learning model in this study was supported by a Moodle-based e-learning campus, called MyBrilian, through the following syntax: (1) Introduction, (2) Exploration, (3) Study, (4) Exposure, and (5) Assessment. This study involved 66 students of Information System university student who took Basic Mathematics courses. The instrument used was the Lesson Plans, Student Learning Materials and Test Instruments. Data analysis through statistical descriptive and qualitative descriptive techniques. Based on the data analysis, it can be concluded that the learning was classified into increased knowledge on a high scale, namely N-Gain of 0.7 , and based on student response questionnaire, it showed satisfactory results in each syntax. It is concluded that the flipped learning model can be adopted as an implementation of planned online learning by adjusting to local learning conditions and with the support of technology.
\end{abstract}

Keywords: Covid-19; Flipped Learning; MyBrillian; Online Learning

How to Cite: Sunarto, M., J., D. (2021). The Development of Flipped Learning Model Based on MyBrilian to Support Planned Online Learning. Jurnal Penelitian dan Pengkajian Ilmu Pendidikan: eSaintika, 5(1), 27-45. doi:https:// doi.org/10.36312/e-saintika.v5i1.379

https:// doi.org/10.36312/e-saintika.v5i1.379

Copyright $\odot$ 2021, Sunarto This is an open-access article under the CC-BY-SA License.

\section{INTRODUCTION}

The impact of the Covid-19 pandemic on education is very pronounced. The pandemic, which is still ongoing today, has both negative and positive impacts, and it won't be fair to see only its negative impacts, but should be more focused on its positive impacts. All over the world, online learning, which has been initiated by education experts for a long time and has difficulty progressing in implementation, has suddenly implemented rapidly due to the pandemic (Onyema, et al., 2020; Rashid \& Yadav, 2020; Mishra, Gupta, \& Shree, 2020; Arnove, 2020; Halil, 2020). A new learning approach has been created due to Covid-19. Although it cannot be denied that this new approach has negative effects, including the perceived imbalance or gap in the world of education, due to unequal access to technology (Soudien, 2020), but that unequality is a homework for stakeholders and policy actors in the world of education to solve. The gap that occurs due to Covid-19 is indeed a bad thing, but 
efforts to overcome it will be a step forward (Hughes, 2020). Each institution in the world of education must think quickly and accurately on what to do to overcome the face-to-face encounters that can't be done during the pandemic, such as the current learning model, so that the pandemic can be resolved as soon as possible. A quick theoretical and literature reviews must be carried out, so that the new learning model can be applied immediately, teachers must be better prepared for changes, hardware can be prepared by the institution so that changes are sought, and as little as possible it is detrimental to students and their parents (Daniel, 2020).

After undergoing the first semester of the pandemic period that occurred suddenly in the institution where this research was carried out and caused impromptu online learning, entering the second semester of the pandemic period, efforts were made to undergo planned online learning. One of the efforts to make planned learning is to create a learning model that is suitable for online learning.

A theoretical study of a learning model absolutely must be done first, because a learning model is a frame of mind that is able to guide someone to carry out learning in order to help students get information, ideas and skills in certain ways (Prahani, et al., 2020). The learning model that will be created have to be aligned with online learning, using the e-learning institution that has been provided, which is named MyBrilian. MyBrilian is a Moodle-based learning application.

From the theoretical study, it was found that learning with the flipped learning model was the most applicable learning model for online learning (Hew, Jia, Gonda, \& Bai, 2020; Kannan, et al., 2020; Lo \& Hew, 2017; Roux \& Nagel, 2018; Gouia \& Gunn, 2016). This flipped model will be used in this study by adding a learning application called MyBrillian to be used as online learning; this is what makes the difference compared to the flipped learning model applied without a learning application.

Flipped learning is a learning model by reversing traditional learning space, where usually students learn new theory in class then do exercises at home, but a new learning model pioneered reverses it (Olaniyi, 2020; Gong, H. Yang, \& Cai, 2020).

In flipped learning, students learn new theory first with teaching materials that have been planned by the educator and its enrichment materials, then discuss it in class (Olaniyi, 2020). The discovery of Flipped Learning by Bergmann and Sams started from their efforts to provide additional lessons for their students who did not attend the class directly. However, Bergmann and Sams were surprised because the results were better than students who attended directly (Kozikoğlu, 2019).

There are several definitions of flipped learning based on the literature. According to Murray, Koziniec, and McGill (2015) is a learning approach in which students learn new knowledge or theories first at home and then in class, they discuss things considered difficult. Meanwhile Stone (2012) state that it is a learning model in which students watch related videos before lessons and spend lesson time studying complex problems, answering questions and establishing relationships with everyday life situations. Gopalan and Klann (2017) state that Flipped Learning as a learning model that very supports learner-centered learning by moving the teacher's role outside the classroom, while in the classroom, students are more active. Meanwhile Kozikoğlu (2019) states that Flipped Learning can be interpreted as a learning model in which students learn the content of courses using videos, presentations, written documents, etc., and take advantage of technological opportunities before meeting 
with educators and learn more deeply in class by discussion, question-answer and practical activities through reinforcement, question-answer and application of background knowledge. While in this study, flipped learning is defined as a learning model, where educators at each meeting always provide teaching materials to be studied first, in the form of documents containing teaching materials (textbooks, student activity sheets, videos and others), then upload those materials via e-campus learning to be studied by students, and educators ensure that all students have learned them before virtual meeting is held so when virtual meeting occurs according to schedule, students can discuss, explore and enrich materials provided by educators.

The novelty of this research is the implementation of flipped learning, with a syntax that is adapted to the conditions in which this research is conducted, and by using a Moodle-based learning application called MyBrilian, which helps both students and educators, in implementing and monitoring each phase, so that online learning changes from impromptu to planned online learning.

Previous learning models were just like face-to-face classes that were moved to virtual face-to-face, even online learning. This learning is sudden and unplanned online learning because online learning must have different characteristics and characteristics from traditional education (Chaeruman, Wibawa, \& Syahrial, 2020). Therefore, a learning model is created, which, although based on flipped learning, also considers the conditions when learning occurs, which is not possible face-to-face. This condition is also supported by data that many students complained about having difficulty understanding online learning material in the first semester of online learning. Data obtained from questionnaires distributed at the end of the first semester of online learning, namely $76 \%$ of students stated that they were not satisfied with the existing learning model.

In this study, a different learning model was made from the previous semester by carrying out the flipped learning model. It was still used by using a learning application on campus, namely MyBrilian, to realize planned online learning. This study aims to develop a learning model based on flipped learning, using the MyBrilian learning application as a planned online learning model during the Covid 19 pandemic. The research problem was how to implement the flipped learning model based on MyBrilian as a form of planned online learning during the Covid-19 pandemic in Basic Mathematics courses? The focus of this study was to determine the implementation process of flipped learning model based on MyBrilian as a form of planned online learning during the Covid-19 pandemic in Basic Mathematics courses.

\section{METHOD}

\section{Sample}

The development of the flipped learning model based on MyBrilian was tested on a limited basis to 66 students in Basic Mathematics class. Students who took Basic Mathematics just entered the first semester of collage. They have experienced online learning at the previous level, i.e at high school, but most of them did not have full experience with online learning, blended synchronous learning and asynchronous learning. 


\section{Instrument and Procedure}

The instruments used for the research were teaching tools, as well as student response questionnaires. The procedure of this current research is illustrated in Figure 1.

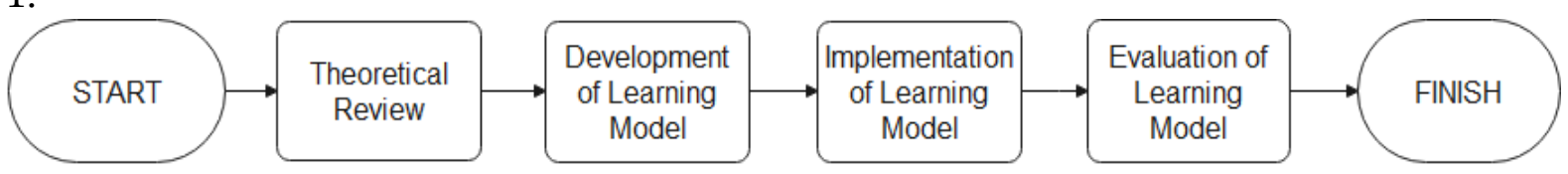

Figure 1. Research Procedure

This research was pre-experimental research with one group pre-test and posttest design (Fraenkel, Wallen, \& Hyun, 2010): O1 X O2, where O1 is the value before learning takes place (pre test) and $\mathrm{O} 2$ is the value after learning takes place (post-test). Starting with making Lesson Plans for Basic Mathematics courses, and followed by teaching tools and instruments for evaluation. Validity and reliability for the Lesson Plan, Teaching Tools, and evaluation sheets were tested for validity and reliability, with the results as shown in Table 1.

Tabel 1. Validity and Reliability of Lesson Plans, Student Learning Material, and Evaluation Instrument.

\begin{tabular}{ccccc}
\hline Learning Instruments & Validity & Category & $\begin{array}{c}\text { Reliability } \\
\mathbf{( \% )}\end{array}$ & Category \\
\hline Lesson Plans & 3.41 & Valid & 94.25 & Reliable \\
Student Learning Materials & 3.35 & Valid & 94.24 & Reliable \\
Test Instruments & 2.79 & Valid & 95.35 & Reliable \\
\hline
\end{tabular}

Table 1 shows that the validity and reliability of lesson plans, student learning materials, and instrument tests are all in the valid and reliable category, so this means that all instruments can be used for this research.

Before using the flipped learning model with MyBrilian, the two students were given a pretest, and after learning with the lesson plans and student learning materials and the same teacher, they were given a posttest.

To determine the effectiveness of the model, data were processed using statistical applications through 3 stages, namely (1) knowing the learning progress of students in both classes and (2) calculate the average N Gain in both classes. N-gain was calculated by the formula (Hake, 1999): $\mathrm{N}$ gain $=$ [post test score - pre test score] / [100-pre test score] with the following categories: (a) High category, if $n$ gain $\leq 0.3$, (b) Medium category if $0.3<$ n-gain $<0.7$, and (c) High category if $n$ gain $\geq 0.7$.

\section{RESULT AND DISCUSSION}

\section{Stage 1: Study of Flipped Learning Theory}

Flipped Learning has been applied at various levels and fields with their respective experiences. Most of them have pleasant and rewarding experience with flipped learning. Among others are in the implementation of flipped learning in an athlete school, to carry out therapeutic modality courses, used a combination of lecture strategies and active learning with scenarios, group discussions or think pair shares, based on materials provided by teachers (Bates \& Ludwig, 2020). A total of 16 students were involved in this Flipped Learning class, and they stated that flipped learning was valuable because it helped students to be more active and ready in their class. 
Meanwhile Wang (2017) tried to evaluate the obstacles occured to educators who implement this flipped learning in their classes, and created a system to overcome the obstacles. Borchardt and Bozer (2017) compared the traditional and the Flipped classes, and obtained data that at the beginning of the process, the traditional class seems to have a superior learning outcome value, but after the end of learning the flipped class is superior. Lee and Lai (2017) tried to apply Flipped Learning to improve the ability of High Order Thinking Skills (HOTS) of 28 students, and got very satisfying results. An interesting finding was obtained by Nouri (2016), who applied flipped learning for students with low presentations and it turned out that these students showed positive attitude and had progress in their learning outcomes, and felt that the learning was more effective.

However, it cannot be denied that flipped learning also has several weaknesses, including the difficulty of students in accessing teaching materials provided by educators before class meetings (Bristol, 2014). Meanwhile, according to Kordyban and Kinash (2016) teachers have difficulty in concluding whether students do it themselves, or asked others to do it, because it occurs outside the classroom. LaFEE (2013) states that the biggest difficulty of flipped learning is the ability of teachers to prepare activities in class and create the best atmosphere in class.

These some existing references that strengthen the further use of the flipped learning model in online learning during a pandemic, because this flipped model is actually designed and developed pedagogically using the help of technology, so as to create the most efficient time in class (Ayçiçek \& Yelken, 2018).

In general, the syntaxes of flipped learning (1) the first day of activities in the flipped learning model, (2) informing the flipped learning model to students, (3) explaining to students how to access the tools used, (4) asking students to prepare questions, (5) guiding students to collaborate, (6) creating a scoring system, and (7) students develop knowledge through data literacy (Bergmann \& Sams, 2012). However, with the same learning model, it is not right to implement it the same way, but it must be adapted to the learning conditions in each learning environment.

\section{Stage 2: Development of MyBrilian-Based Flipped Learning Model}

During the pandemic, face-to-face learning cannot be done, so online learning must be used instead. The institution where this current research was carried out then tried to develop and improve the existing campus e-learning. Campus e-learning, which was originally based on Google Apps for Education, was changed to Moodlebased because it was felt to be more sophisticated in meeting users' needs and friendly-use. The new e-learning is called MyBrilian. In addition to the tools prepared, lecturers were also being trained on appropriate learning models for online learning. The development of the new learning model, is adapted from flipped learning by adjusting the conditions of local students. In this learning model, the emphasis is on $70 \%$ independent learning experience and $30 \%$ on mentoring and coaching, according to the pattern of the flipped learning model to create active participation from students (Wang \& Zhu, 2019). In addition, this model is expected to be able to initiate and raise Self Directed Learning in students at the same time, by training their independent learning ability, so students are used to critical thinking and self-reflection (Akgunduz \& Akinoglu, 2016). The development of MyBrilian-based flipped learning model is 
described in table 2, so that it can be used as a guide for the preparation of teaching tools by educators.

Table 2. Development of MyBrilian-based Flipped Learning Model

$\begin{array}{ll}\text { Syntax of Flipped Learning Model } & \text { Syntax of the Development of } \\ & \text { MyBrilliant-Based } \\ & \text { Learning Model }\end{array}$

\begin{tabular}{lc}
\hline $\begin{array}{l}\text { The activities at the first day of the flipped } \\
\text { learning model } \\
\text { Informing the flipped learning model to } \\
\text { students }\end{array}$ & Introduction \\
\hline $\begin{array}{l}\text { Explaining to students how to access the } \\
\text { used tools }\end{array}$ & Exploration \\
\hline Asking students to prepare questions & Study \\
\hline Guiding students to collaborate & Presentation \\
\hline $\begin{array}{l}\text { Creating scoring system } \\
\text { literacy }\end{array}$ & \\
\hline
\end{tabular}

\section{Stage 3: Implementation}

After the syntax is formed, educators make lesson plans using the guidelines from the syntax. The description and examples of the syntax implementation used are as follows.

\section{Phase I: Introduction}

In this phase, educators try to attract students' attention, focus on the teaching and learning process, and motivate them to take an active role in each process. This is very important to do because this is the foundation for growing learning enthusiasm of students. In this phase, educators have prepared teaching tools that are made as attractive as possible using the assistance of information technology facilitated by the institution, as stated in the book The eLearning guild's handbook on Synchronous eLearning (Hyder, Kwinn, Miazga , \& Murray, 2017) namely: (1) the understanding of the philosophy of synchronous mode (readiness of educators as content creators, readiness of e-learning application features, readiness of producer to handle the whole process), (2) the understanding of designing a virtual classroom (how long this mode will be used so it won't be boring, how to maximize interaction, the means to create a virtual classroom), (3) the preparation to create a synchronous mode (introduction to learners that will be faced in virtual classrooms, the need of teaching assistants or not, making appropriate instructional designs, preparing supporting hardware, (4) attention during the learning in synchronous mode, (5) evaluating the results.

The role of MyBrilian learning application is very important here, because in this introduction phase, educators need to show interesting teaching materials that have been prepared, along with an understanding of the role play of learning that will be undertaken by students. Through the menu that can be selected on MyBrilian, including File, Label, URL or Page, educators can greet students, before there is an official meeting scheduled from campus. 


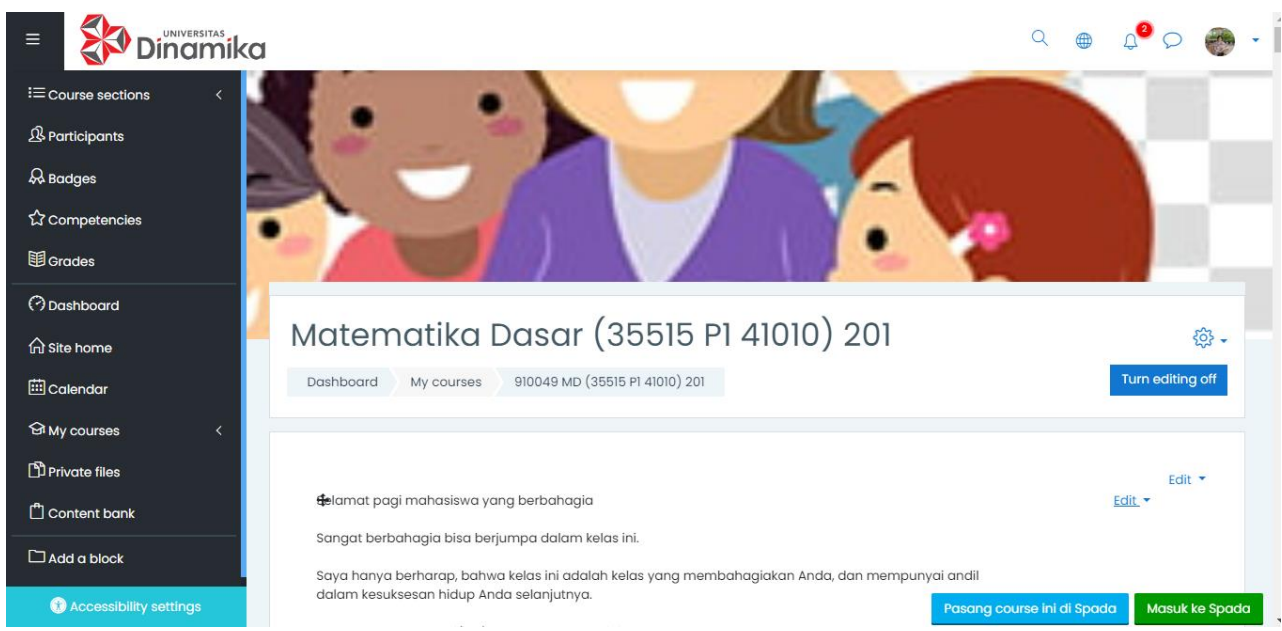

Figure 2. The Display of the First Meeting of Basic Mathematics Class using the Label Menu in the Mybrilian Application

Teaching material had to be uploaded at least a week before the scheduled class, so that students can read not only the materials that must be studied, but also how class will take place, in order to motivate students to join and learn together. This is in accordance with Piaget's opinion (Moreno, 2010), that students are natural explorers, who will always be curious to try to further understand their knowledge, when they are already interested in a particular material or thing. Apart from going through MyBrilian, educators also created Whatsapp groupe (WAGe), where the invitations to join group are via MyBrilian dan WA links. In addition, role play and Lesson Plan for a semeseter are included so that students already know materials to be studied in one semester.
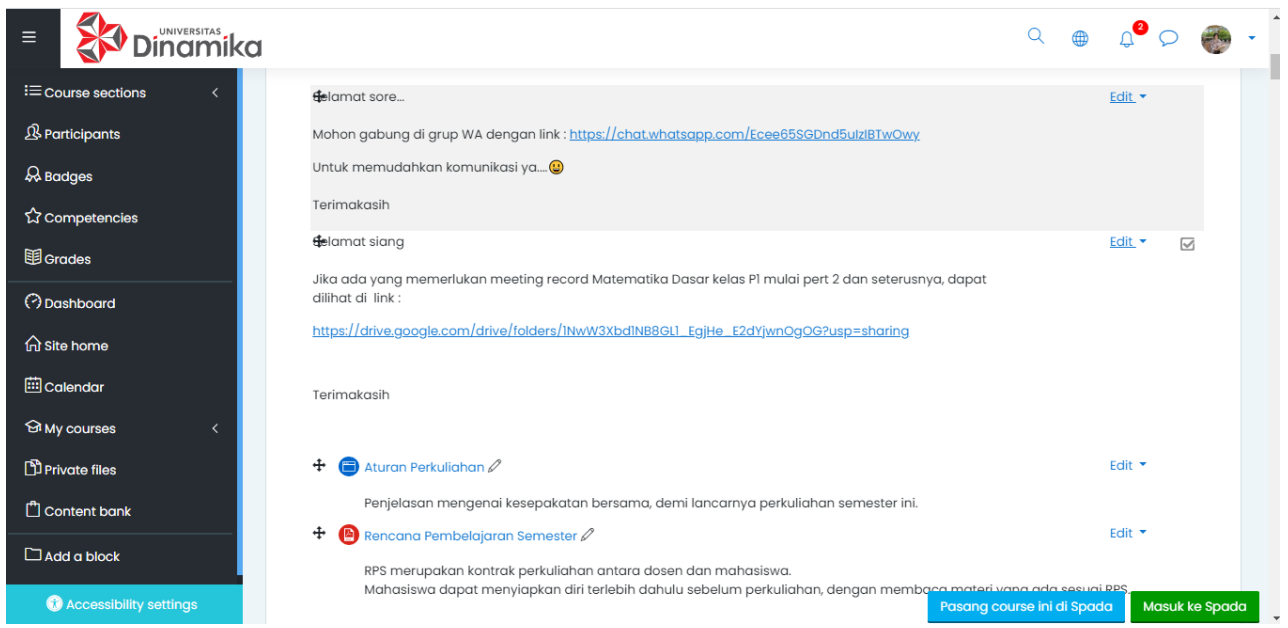

Figure 3. The Display of Invitation link to Join WAG, Role Play and RPS in Mybrilian Application

This phase is supported by cognitive theory which explains that when students are with peers, changes in mental structures will occur, as a result of individual interactions with the environment (Prahani, et al., 2020). By sharing ideas with fellow students, it will increase students' understanding more quickly, as is known as distributed cognition learning (Moreno, 2010). The basis of phase 1 is Dewey's theory (Loughran, 2013) which states that materials in school must be made as concrete and attractive as possible for students so that student exploration ability increases. 
This phase is carried out outside of the learning hours set by the institution, because it is a preparation for students to present their ideas in the next phase.

\section{Phase II: Exploration}

In this phase, students learn first teaching material that have been uploaded by educators on MyBrilian, through the folder or file menu, at each scheduled meeting, as shown in Figure 4. Materials from educators are uploaded no later than one week before the official class schedule, so that students can learn them. During one week period, it is possible for students and educators to discuss through WAG or through the Forum menu in MyBrilian, as an example in Figure 5. Students actively construct their knowledge, starting from personal experience to discussions with their peers and environment (Moreno, 2010). Through discussion, educators help to understand pedagogic knowledge and advanced knowledge to be applied to other fields, so it sharpens the higher-order thinking skill (Eggen \& Kauchak , 2013). This phase is carried out outside the regular hours set by the institution, because it is a preparation for students to enter the review phase.

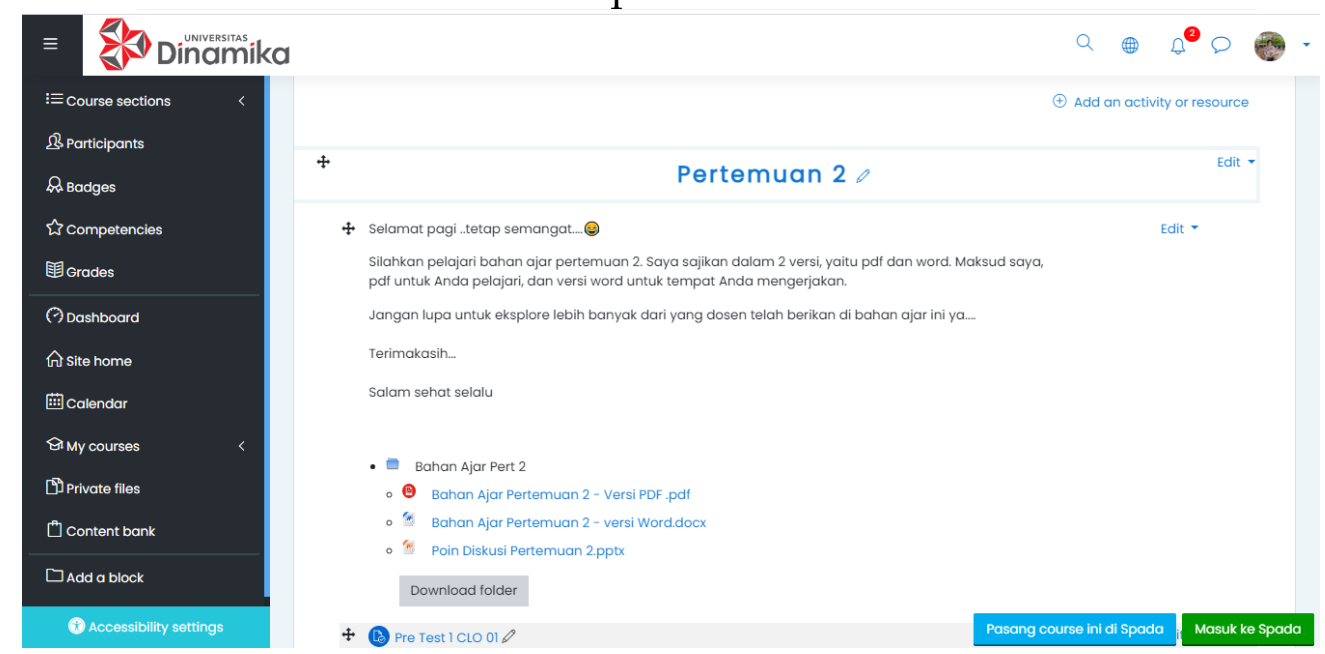

Figure 4. Example of the display of teaching materials in the Mybrilian application

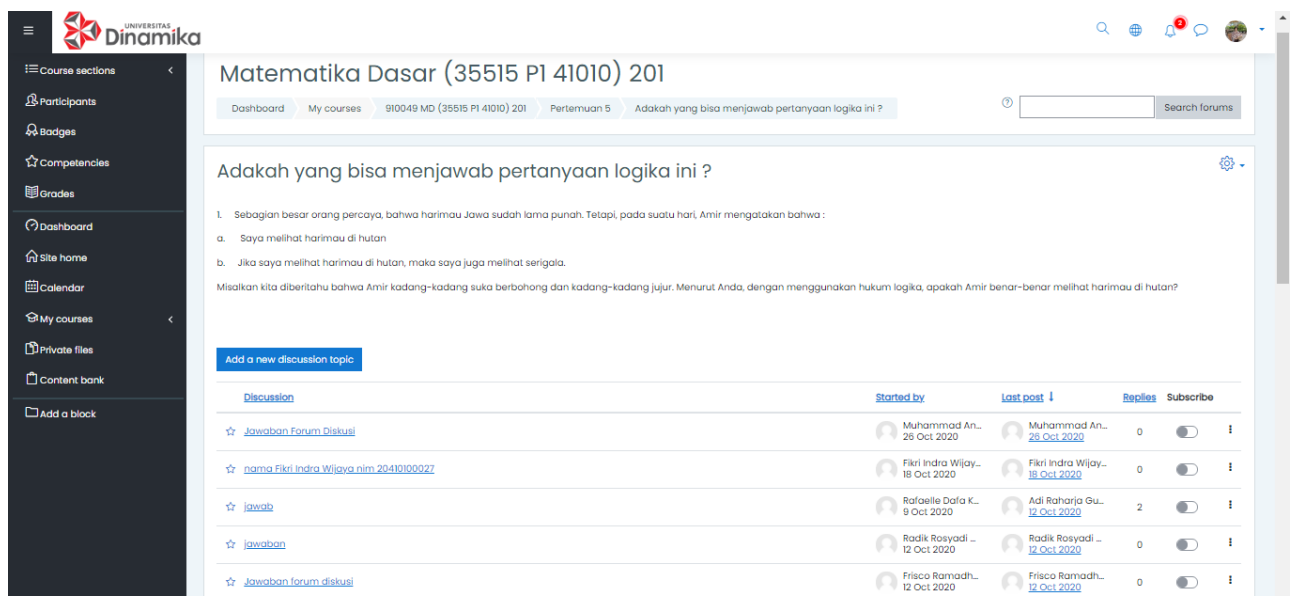

Figure 5. Example of Forum Menu for Discussion Between Educators and Students

\section{Phase III: Study}

The purpose of this phase is to guide students in making analysis, conclusions and discussion of the assessment phase. This phase is based on Vygotsky's theory (Moreno, 2010; Eggen \& Kauchak , 2013; Slavin, 2011), which has 4 learning principles, 
namely a) Social Learning, in which students are active to shape their knowledge, through personal experience and interaction with peers, b) Zone of Proximal Development (ZPD), i.e assistance that must be provided, if students really need to reach a higher level of knowledge, c) cognitive apprenticeship, which is an apprenticeship or learning with adults, or friends who are considered to have mastered material first, d) The usse of scaffolding to help students achieve goals. So, in this phase students and educators actively communicate, both through WAG and google meet so that students are ready to enter the next phase.

This phase is carried out outside the regular hours set by the institution, because it is a preparation for students to present their ideas in the fourth phase.

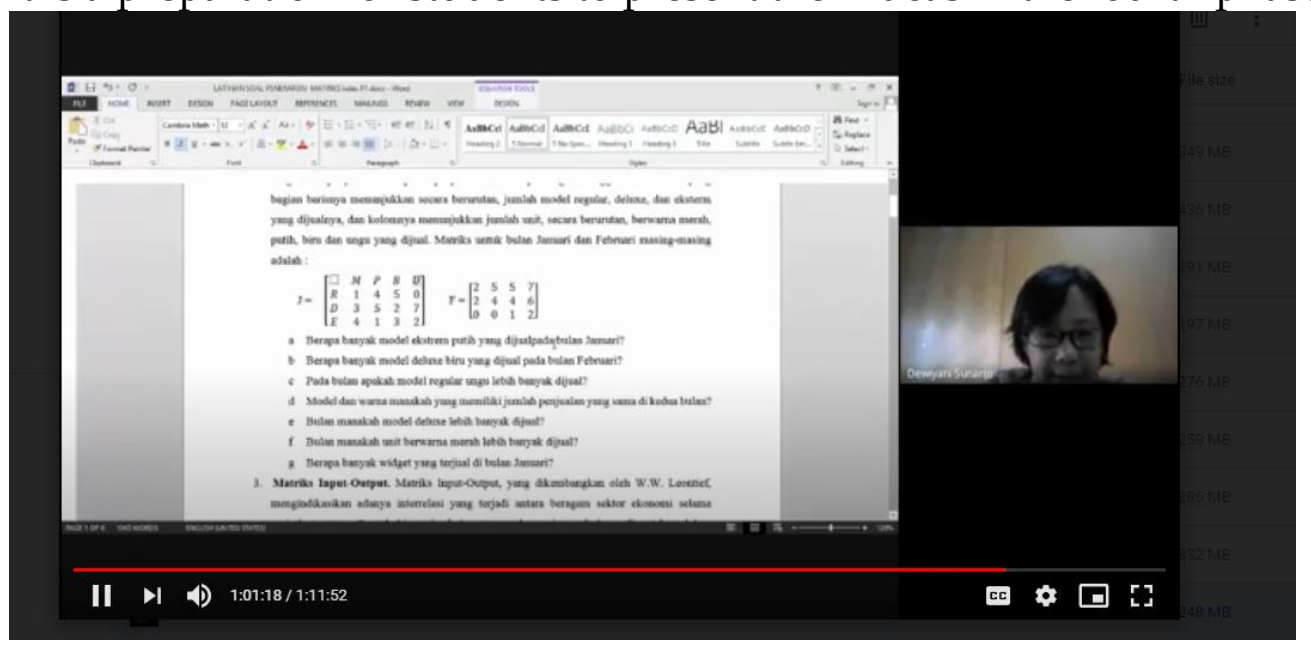

Figure 6. Example of activities in the review phase using Google Meet

\section{Phase IV: Presentation}

In this phase, students will present the results of the previous phases, i.e after knowing, exploring and studying material that has been determined by educators, look for literacy from many sources, discuss with friends and educators, and try to rewrite it in their own words until they understand it. After understanding material, students need to present the results of their understanding and conclusions to friends and educators in the form of presentation. The purpose of this phase is to familiarize students with planning, preparing, and then presenting the results, so that students learn to sharpen their communication skills and critical thinking (Prahani, et al., 2020). This phase is carried out on a routine schedule determined by the institution.

\section{Phase V: Assessment}

In this phase, students will undergo an assessment, as a result of their efforts during the previous phases. Students must work on a problem solving, still online, by going through the Assignment menu in MyBrilian, where on the menu, the processing time can be set, so that students have the ability to set time for problem solving. Students' works which are based on literacy and problem solving can be used as learning evidence (Prahani, et al., 2020). 


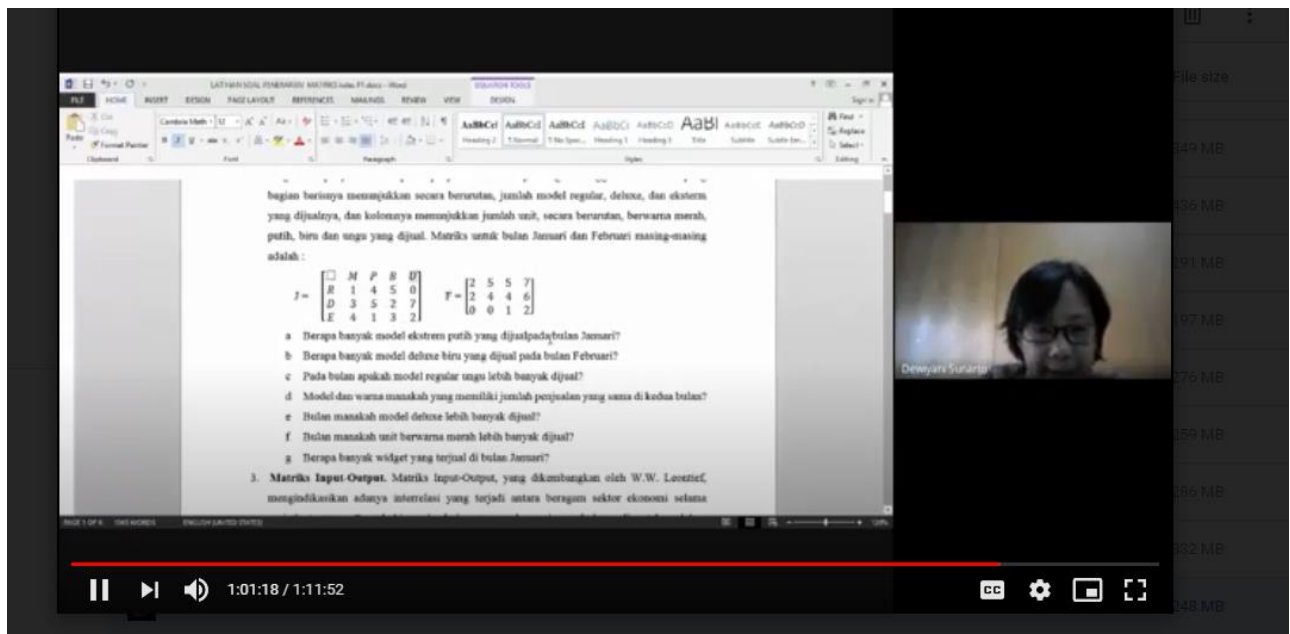

Figure 6. Example of Assessment with the Assignment Menu from the MyBrilian Application

\section{Stage 4: Evaluation}

Evaluation of the syntax of the learning model was carried out by measuring the success of the learning, and looking for data through the responses of students to the learning that has been done (Hwang \& Lai, 2020).

Based on the score of students' basic mathematics learning outcomes before and after MyBrilian-based flipped learning model, the average score of the pre-test and post-test as shown in Table 3.

Table 3. Average Value of Pre Test, Post Test and N Gain for 2 classes: Basic Mathematics P1 and Basic Mathematics P2

\begin{tabular}{ccccccc} 
Grup & \multicolumn{3}{c}{ MD P1 : N =33 } & \multicolumn{3}{c}{ MD P2 : N = 36 } \\
\cline { 2 - 7 } & Pre Test & Post Test & N Gain & Pre Test & Post Test & N Gain \\
\cline { 2 - 7 } & 24.54 & 76.84 & 0.70 & 27.52 & 78.58 & 0.71 \\
\hline
\end{tabular}

Table 3 shows that there is an increase in the scores of learning outcomes, both in the basic mathematics groups for P1 and P2, before and after MyBrilian-based flipped learning model. Before using the learning model, the pre-test score is very low, below 30, on a scale of $0-100$, while after that, there is an increase in both classes and is able to reach score above 70 , on a scale of $0-100$. While the $\mathrm{N}$ gains of both classes are in high category (Hake, 1999).

In order to test the increase in students' basic mathematics outcomes, first, reserchers tested the assumption of normality toward the n-gain of the pre-test and post-test in both groups of students by using Kolmogorov-Smirnov (Table 4) and followed by the Wilcoxon test (Table 5).

Tabel 4. Normality Test Results

\begin{tabular}{lcccr}
\hline & \multicolumn{3}{c}{ Kolmogorov-Smirnov $^{\mathbf{a}}$} \\
\hline & Statistic & & df & Sig. \\
\hline O1A & .142 & & 33 & .089 \\
O2A & .140 & 33 & .098 \\
NGAIN_A & .424 & 33 & .000 \\
O1B & .103 & 33 & $.200^{*}$ \\
O2B & .183 & 33 & .007 \\
NGAINB & .158 & 33 & .035 \\
\hline
\end{tabular}


Based on the Kolmogorov-Smirnov normality test results in Table 4, it can be concluded that the data is normally distributed only in the N-Gain class P1 and the NGain class P2. In contrast, the pre-test and post-test classes P1 and Class P2 are not normally distributed. Therefore, non-parametric inferential statistics are used.

Tabel 5. Wilcoxon Test Results

\begin{tabular}{lll}
\hline Wilcoxon Test Results & Group P1 & Group P2 \\
\hline Z & $-5.014^{\mathrm{a}}$ & $-5.648^{\mathrm{a}}$ \\
Asymp. Sig. (2-tailed) & .000 & .000 \\
\hline
\end{tabular}

Based on the Wilcoxon Signed Rank Test calculation results, the $Z$ values obtained are $-5,014$ and $-5,648$ with p values (Asymp. Sig 2 tailed) of .000 and .000 where $<0.05$. So it can be concluded that there is a significant difference between the pre-test and post-test groups.

Tabel 6. Mann Whitney Test Results.

\section{Test Statistics ${ }^{b}$}

\begin{tabular}{ll}
\hline & NGAIN_P1_P2 \\
\hline Mann-Whitney U & 589.000 \\
Wilcoxon W & 1255.000 \\
Z & -.060 \\
Asymp. Sig. (2-tailed) & .952 \\
\hline
\end{tabular}

Table 6 above shows the $U$ value of 589,000 and the $W$ value of 1255,500 . When converted to a $Z$ value, the amount is -.060 . The Sig or P-Value is .952>0.05. If the $p$ value $>$ critical limit $\alpha=5 \%$, it can be concluded that there is no difference in $\mathrm{N}$-gain between the two groups (P1 \& P2).

In addition to comparing the results of learning scores, educators also provided questionnaires for knowing students' responses, consisting of 5 closed questions and 1 open question. The results of the student response questionnaire can be seen in Figures 7, Figure 10 to Figure 13.

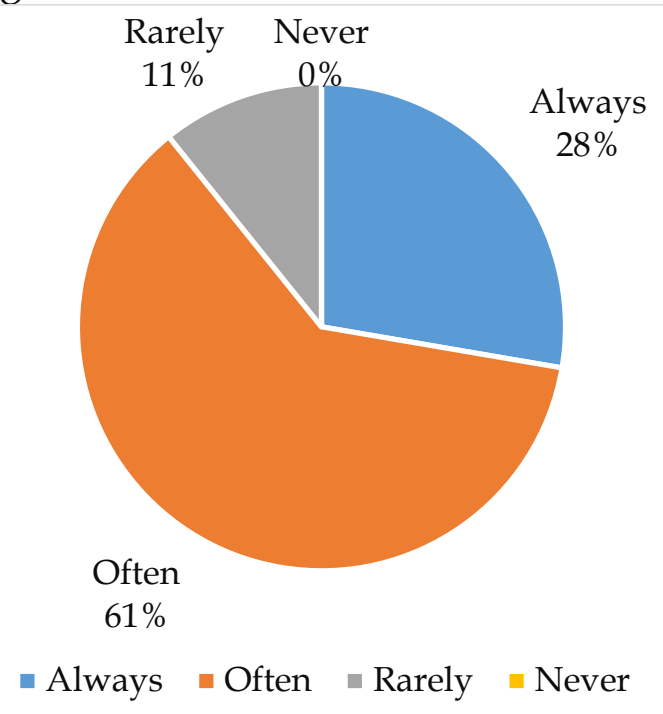

Figure 7. Results of Student Response Questionnaire on Activeness in Studying Material Before the Routine Schedule (Introduction Phase) 
From the results of student response questionnaires on the activeness of studying material before the predetermined schedule, it can be seen that learning material given by educators before class has not become a habit. Only $28 \%$ of students stated that they always learn beforehand. This is indeed felt by educators, especially at the beginning of lectures, educators must constantly remind through WAGs the importance of having independent learn ability, to anticipate and be ready to enter the era of the industrial revolution 4.0 and Soceity 5.0, if they have lifelong learning abilities (Boyer, Edmondson, Artis, \& Fleming, 2014). It is not easy to embed this understanding in students, because they rarely experienced things like this previously. However, with the understanding and assistance of one of the menus in MyBrilian, i.e the Report menu, educators can check on students who have not opened the teaching material given. Habits with the help of technology like this turned out to be able to gradually change students' habits (Raja \& Nagasubramani, 2018), until 61\% of them stated that they often opened teaching materials first. The example of the monitoring result of students' activeness in opening teaching materials from the MyBrilian application, both for the whole class and for each student, can be seen in Figures 8 and Figure 9.

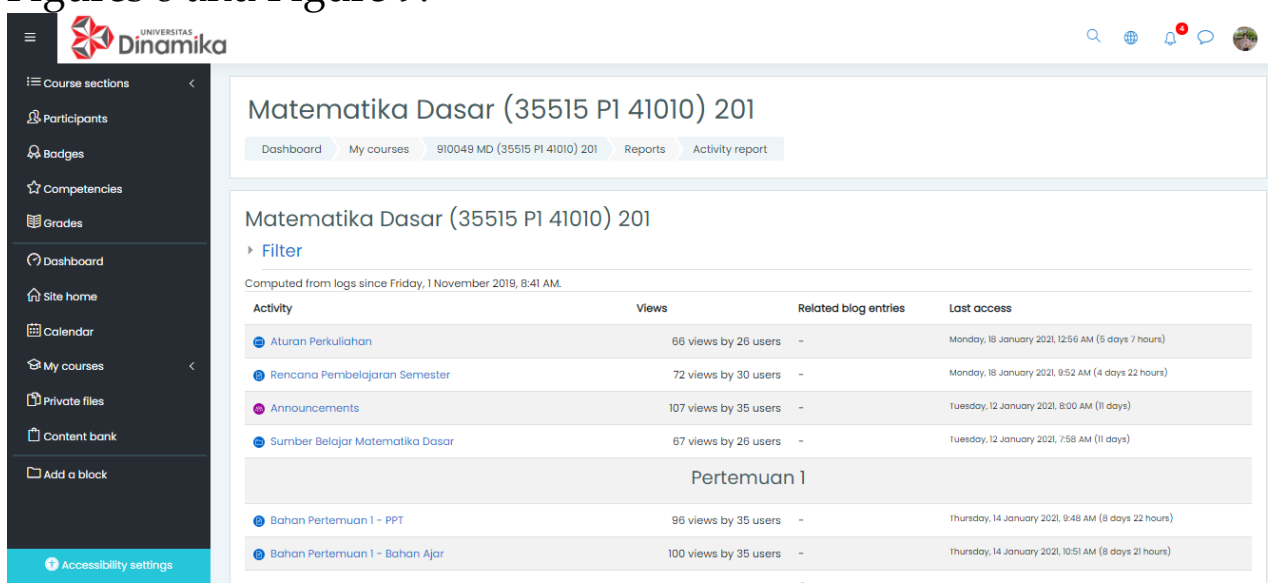

Figure 8. The Example of the Monitoring Result of Students' Activeness in a Class in Opening Teaching Materials from My Brilliant Application.

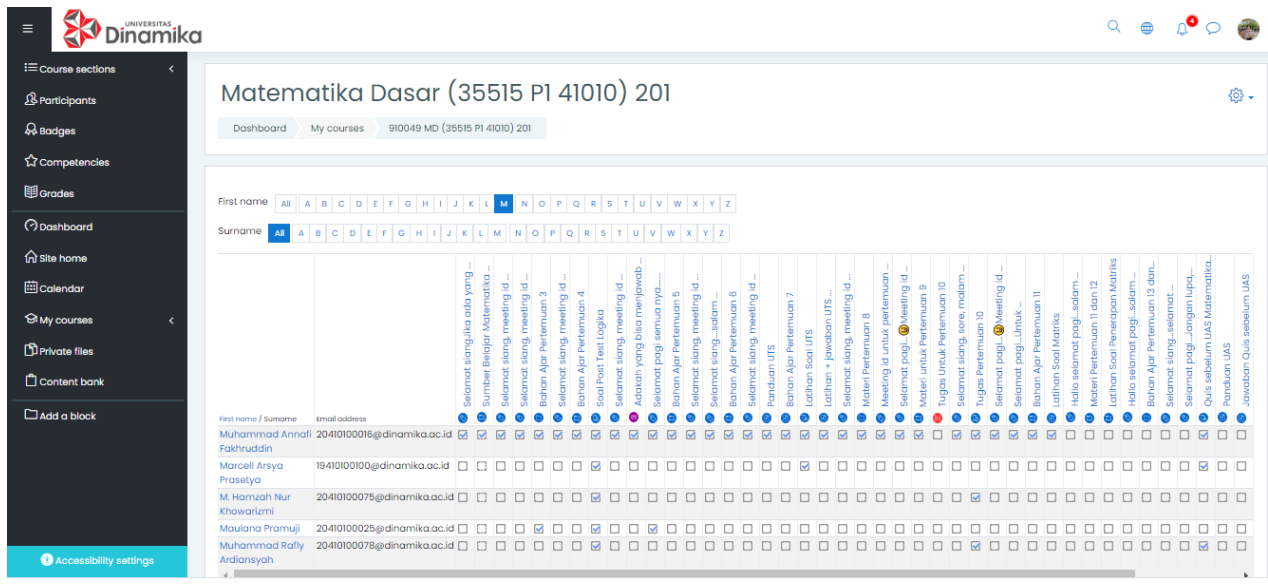

Figure 9. The Example of Monitoring Result of Individual Students' Activeness in Opening Teaching Materials from MyBrilian Application 


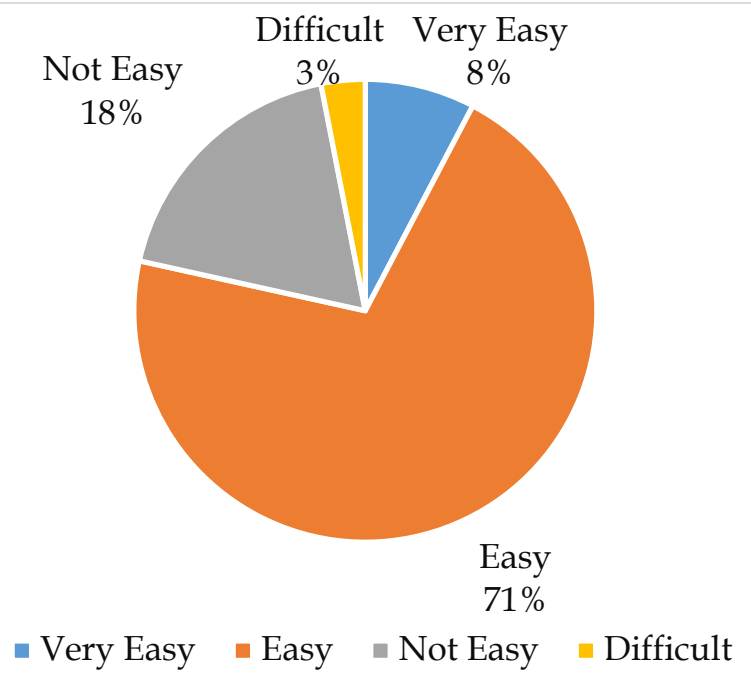

Figure 10. The Results if Student Response Questionnaire on the Ease of Understanding Teaching Materials in MyBrilian Application (Exploration Phase)

Teaching materials and teaching aids are important to attract students' attention in learning certain materials (Lee, Chao, \& Chen, 2011). With advances in technology, teaching materials can be made as attractive as possible because it is in accordance with the development of students, so it is more possible to invite students to learn a certain material (Abadi, Pujiastuti, \& Assaat, 2017). In this study, teaching materials were made with qrcode links to connect with videos taken from the Internet. With videos in teaching materials, the next step is that students are expected to develop literacy through technology. From the student response questionnaire, it was found that $71 \%$ stated that it was easy to learn teaching materials made by educators, but educators realized that the quality and ease of teaching materials have to be improved so that they can be assessed easily by the majority of students.

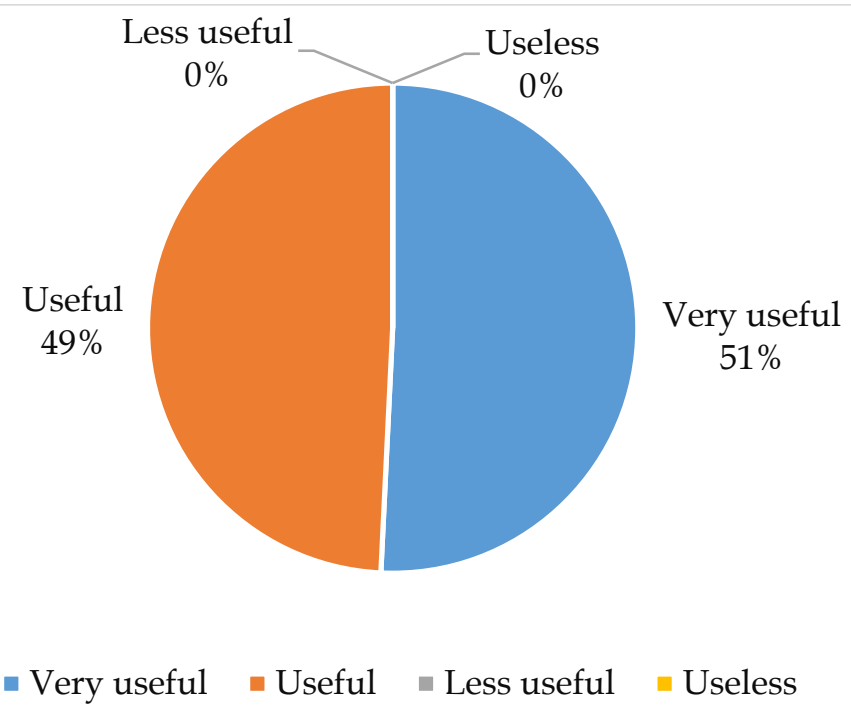

Figure 11. Results of Student Response Questionnaires about Students' Opinions on the Existence of Teaching Materials before Undergo Virtual Meeting (Study Phase) 
In this study phase, students can already gain the benefits of teaching materials provided before the routine schedule. This is because students can prepare in advance so they won't be left behind in this phase. In this phase, educators and students actively discuss with each other outside routine hours, to prepare for the next phase. Of course, students who do not read materials beforehand will not get complete understanding during this discussion. This phase makes students develop with friends and their environment, especially in this phase, students can implement Bruner's theory for discovery (Slavin, 2011). Educators can also provide Scaffolding in this phase, namely high-quality support for students, which is built through collaborative interactions and mediated by verbal interactions (Pol, Volman, Oort, \& Beishuizen, 2015). This phase is considered very beneficial for students' development, because educators can observe and discuss freely without time constraints such as on a routine schedule.

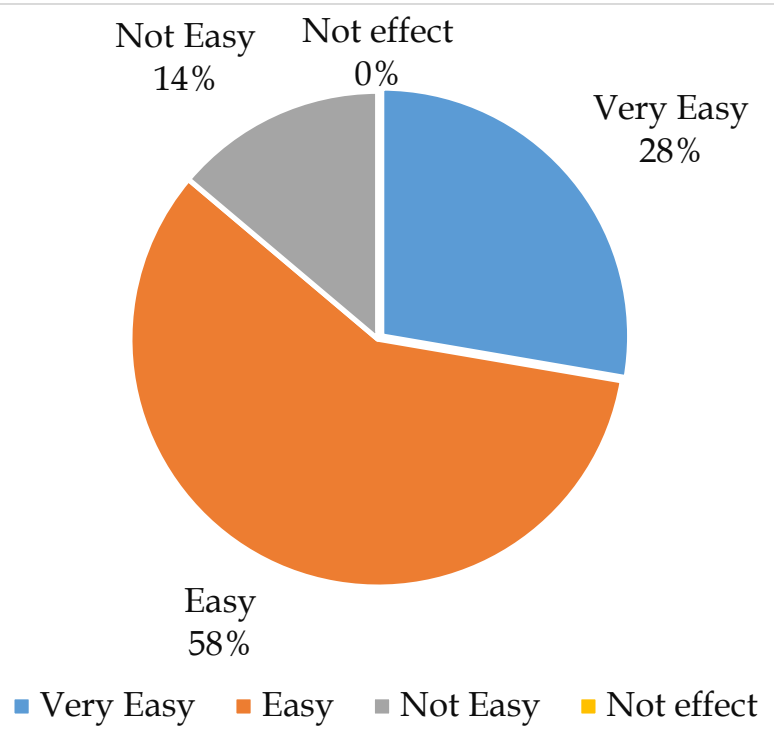

Figure 12. The Result of Student Response Questionnaire on the Impact of Students' Preparation in Reading Teaching Materials Before Virtual Meeting (Presentation Phase)

In this presentation phase, where students must be able to present their results of the preparation for the previous 3 phases, it does require thorough understanding. In this phase, students will find out that it is easy if they have studied teaching materials beforehand. The results of response questionnaire stated that $58 \%$ of students states it is easy, and $14 \%$ states that it is very easy in undergoing this fourth phase, if the preparation, i.e in the form of understanding teaching materials and development through literacy, had been done well. It is very important to familiarize students with presentation phase, because the ability to present an idea is one of the 4C (Creative, Critical Thinking, Collaboration, and Communication) skills that students must master (Triana, Anggraito, \& Ridlo, 2020; Dwikoranto, Setiani, \& Prahani, 2020). 


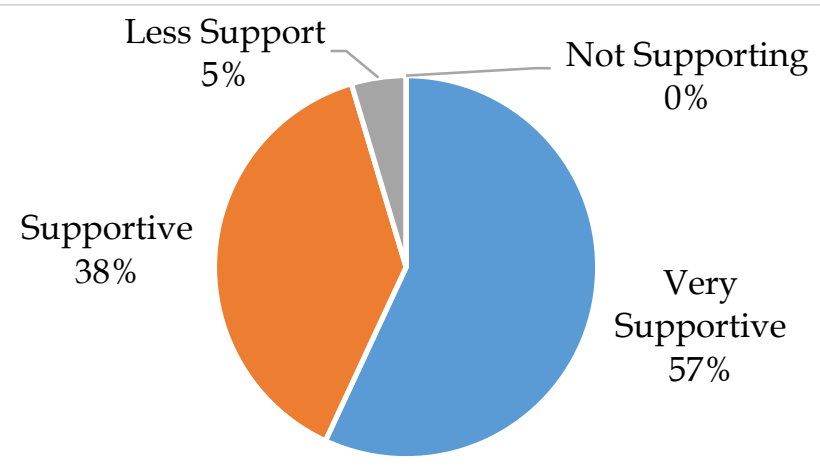

घ Very Supportive $\quad$ - Supportive $\quad$ - Less Support $\quad$ Not Supporting

Figure 13. The result of Student Response Questionnaire on the Effect of Virtual Meeting on Material Understanding (Evaluation Phase)

In this last phase, through student response questionnaires, students state that no matter what material has been made and studied, no matter how preparations have been made, online learning through virtual meeting with educators, is still needed for the perfection of students' understanding. The touch of educators, although not direct meeting, brings different nuances and influences to students, because students are still social beings who need interaction and communication with each other (Martin \& Parker, 2014). Of course, the impact of phases 1-4 will be felt in this evaluation. However, keeping in mind that N-Gain is in the High category, the result in each phase is good, although of course there is still much to be improved.

Towards open questions, students respond positively, by average students express their liking to the learning model applied, one answer that really represent what is being asked is:

I am so happy with the material uploaded to MyBrilian before the class started, it makes me easier in understanding and studying the material first beforehand, and if there is a task given, I can do it easier because I have studied it previously and just need to search for additional material from Google that I have not understood or if there are other difficulties during the process of working on the task. Thank you ma'am for the enthusiasm and positive words that you give to students who are still transitioning from high school level to university level. Always prepare before class started in order to simplify the process of learning and teaching activities during the class and always ask us to be enthusiastic and to be more active in class, especially in Mrs. Dewiyani's class. Wish you good health and happiness :)

There are also positive suggestions, including; reproduce examples, and files' names of the teaching tools adjusted to the name of materials.

\section{CONCLUSION}

The Flipped Learning model supported by the MyBrilian application based on Moodle had been completed for one semester in the Basic Mathematics course for students in semester 1. The Basic Mathematics course trains students' logical thinking, so that it can be used for problem solving. The role of this course was hence vital enough to support the success of the main courses in the study program. Therefore, 
the Basic Mathematics course must be endeavored so that it can be mastered properly by students. Online learning causes educators to change their learning model. If it is only done in a way like switching direct face-to-face to virtual meeting, students can not catch it well, because of the many distortions in the online learning process.The result shows that an increase in knowledge on a high scale of 0.7 could change learning outcomes from under 30 to above 70 (on a scale of $0-100$ ). In addition, most of the students' opinions on each syntax are positive.

This research gained awareness that if students are given opportunity to explore, express opinions, and develop knowledge using technology, it turns out to provide results that are beyond students' expectations. Students are also more able to enjoy the learning process that takes place using technological advances they used daily.

\section{RECOMMENDATION}

The limitation of this study is the existing syntaxes have not been tested extensively in other courses, and on other educators. Recommendation for further research is that the learning model can be tested on students in higher level, with main courses in the Information Systems study program, and different educators.

\section{ACKNOWLEDGEMENT}

My big gratitude to Universitas Dinamika, Surabaya, Indonesia for allowing its two classes to be the current research subjects. This paper also serves as a deep gratitude to a colleague in this current research who had been passed away, Dra. Nining Martiningtyas, M.MT, May God rest her soul in peace.

\section{REFERENCES}

Abadi, M. K., Pujiastuti, H., \& Assaat, L. (2017). Development of Teaching Materials Based Interactive Scientific Approach towards the Concept of Social Arithmetic For Junior High School Student. International Seminar on Mathematics, Science, and Computer Science Education (MSCEIS 2016) (pp. 1-7). Bandung : IOP.

Akgunduz, D., \& Akinoglu, O. (2016). The Effect of Blended Learning and Social Media-Supported Learning on the Students' Attitude and Self-Directed Learning Skills in Science Education. TOJET: The Turkish Online Journal of Educational Technology, 15(2), 106-115.

Arnove, R. F. (2020). Imagining what education can be post-COVID-19. Prospects, 49, 43-46.

Ayçiçek, B., \& Yelken, T. Y. (2018). The Effect of Flipped Classroom Model on Students' Classroom Engagement in Teaching English. International Journal of Instruction, 11(2), 385-398.

Bates, D., \& Ludwig, G. (2020). Flipped classroom in a therapeutic modality course: students' perspective. Research and Practice in Technology Enhanced Learning, 15(18), 1-15.

Bergmann, J., \& Sams, A. (2012). Flip Your Classroom: Reach Every Student in Every Class Every Day. Washington DC: Internal Society for Technology in Education.

Borchardt, J., \& Bozer, A. H. (2017). Psychology course redesign: an interactive approach to learning in a micro-flipped classroom. Smart Learning Environments, $4(10), 1-9$. 
Boyer, S. L., Edmondson, D. R., Artis, A. B., \& Fleming, D. (2014). Self-Directed Learning: A Tool for Lifelong Learning. Journal of Marketing Education, 36(1), 2032.

Bristol, T. (2014). Educate, Excite, Engage : Flipping the Classroom. Teaching and Learning in Nursing, 9, 43-46.

Chaeruman, U. A., Wibawa, B., \& Syahrial, Z. (2020). Development of an Instructional System Design Model as a Guideline for Lecturers in Creating a Course Using Blended Learning Approach. International Journal of Interactive Mobiles Technologies, 164-181.

Daniel, S. J. (2020). Education and the COVID-19 pandemic. Prospects 49, 49, 91-96.

Dwikoranto, D., Setiani, R., \& Prahani, B. K. (2020). Mobile Learning to Improve Student Collaborative Skills: An Alternative to Online Learning in the Era of Covid-19 Pandemic. Jurnal Penelitian dan Pengkajian Ilmu Pendidikan: e-Saintika, 4(3), 259-271.

Eggen, P., \& Kauchak , D. (2013). Educational Psychology: Windows on Classrooms. New York: Pearson.

Fraenkel, J. R., Wallen, N. E., \& Hyun, H. H. (2010). How to Design and Evaluate Research in Education (Eight Edition). New York : Mc Graw-Hill.

Gong, D., H. Yang, H., \& Cai, J. (2020). Exploring the key influencing factors on college students' computational thinking skills through flipped-classroom instruction. International Journal of Educational Technology in Higher Education, 17(19), 1-13.

Gopalan, C., \& C Klann, M. (2017). The effect of flipped teaching combined with modified team-based learning on student performance in physiology. Advances in Physiology Education, 41(3), 363-367.

Gouia, R., \& Gunn, C. (2016). Making mathematics meaningful for freshmen students: investigating students' preferences of pre-class videos. Research and Practice in Technology Enhanced Learning, 11(2), 1-8.

Hake, R. (1999). Analyzing Change/ Gain Score. Indiana: Indiana University.

Halil, N. I. (2020). The Effectiveness of Using Edmodo as an Online Learning Platform in Covid 19. Jurnal Penelitian dan Pengkajian Ilmu Pendidikan: e-Saintika, 4(3), 284298.

Hew, K. F., Jia, C., Gonda, D. E., \& Bai, S. (2020). Transitioning to the "new normal" of learning in unpredictable times: pedagogical practices and learning performance in fully online fipped classrooms. International Journal of Educational Technology in Higher Education, 17, 1-22.

Hughes, C. (2020). COVID-19 and the opportunity to design a more mindful approach to learning. Prospects , 49, 69-72.

Hwang, G. J., \& Lai, C. L. (2020). Facilitating and Bridging Out of Class and In Class Learning : an Interactive E-Book-Based Flipped Learning Approach for Math Courses. Educational Technology \& Society, 20(1), 184-197.

Hyder, K., Kwinn, A., Miazga , R., \& Murray, M. (2017). The eLearning guild's handbook on Synchronous e-Learning. Santa Rosa, CA: The elearning Guide.

Kannan, V., Kuromiya, H., Gouripeddi, S. P., Majumdar, R., Warriem, J. M., \& Ogata, H. (2020). Flip \& Pair - a strategy to augment a blended course with activelearning components: effects on engagement and learning. Smart Learning Environments, 7(34), 1-23. 
Kordyban, R., \& Kinash, S. (2016, July 10). Education Technology Solutions. Retrieved from https:/ / educationtechnologysolutions.com/2016/07/flipped-classroom/

Kozikoğlu, İ. (2019). Analysis of the Studies Concerning Flipped Learning Model: A Comparative Meta-Synthesis Study. International Journal of Instruction, 12(1), 851868.

LaFEE, S. (2013, November). The Education Digest. Retrieved from https://espforuniversityprep.weebly.com/uploads/2/8/8/6/28861675/flippe d_learning_lafree_2013.pdf

Lee, K.-y., \& Lai, Y.-c. (2017). Facilitating higher-order thinking with the flipped classroom model: a student teacher's experience in a Hong Kong secondary school. Research and Practice in Technology Enhanced Learning, 12(8), 1-14.

Lee, Y.-J., Chao, C. -H., \& Chen, C. -Y. (2011). The influences of interest in learning and learning hours on learning outcomes of vocational college students in Taiwan: using a teacher's instructional attitude as the moderator. Global Journal of Engineering Education, 13(3), 140-153.

Lo, C. K., \& Hew, K. F. (2017). A critical review of flipped classroom challenges in K12 education: possible solutions and recommendations for future research. Research and Practice in Technology Enhanced Learning, 12(4), 1-22.

Loughran, J. (2013). Developing a pedagogy of teacher education : Understanding teaching $\mathcal{E}$ learning about teaching. New York: Routledge .

Martin, F., \& Parker, M. A. (2014). Use of Synchronous Virtual Classrooms: Why, Who, and How? MERLOT Journal of Online Learning and Teaching, 10(2), 192-210.

Mishra, L., Gupta, T., \& Shree, A. (2020). Online teaching-learning in higher education during lockdown period of COVID-19 pandemic. International Journal of Educational Research Open, 1, 1-8.

Moreno, R. (2010). Educational Psychology. New York : John Wiley \& Son. Inc .

Murray, D., Koziniec, T., \& McGill, T. (2015). Student Perceptions of Flipped Learning. Australasian Computer Education Conference (ACE). 37, pp. 57-62. Sydney, Australia: ACM Digital Library.

Nouri, J. (2016). The flipped classroom: for active, effective and increased learning especially for low achievers. International Journal of Educational Technology in Higher Education, 13(33), 1-10.

Olaniyi, N. E. (2020). Threshold concepts: designing a format for the flipped classroom as an active learning technique for crossing the threshold. Research and Practice in Technology Enhanced Learning, 15(2), 1-15.

Onyema, E. M., Eucheria, N. C., Obafem, F. A., Sen, S., Atonye, F. G., Sharma, A., \& Alsayed, A. O. (2020). Impact of Coronavirus Pandemic on Education. Journal of Education and Practice, 13(10), 108-121.

Pol, J. v., Volman, M., Oort, F., \& Beishuizen, J. (2015). The effects of scaffolding in the classroom: support contingency and student independent working time in relation to student achievement, task effort and appreciation of support. Instr Sci, $43,615-641$.

Prahani, B. K., Jatmiko, B., Sunarto, D., Hariadi, B., Sagirani, T., Lemantara, J., \& Amelia, T. (2020). Blended Web Mobile Learning (BWML) Model to Improve Students' Higher Order Thinking Skills. International Journal of Emerging Technologies in Learning (iJET), 15(11), 42-55. 
Raja, R., \& Nagasubramani, P. (2018). Impact of modern technology in education. Journal of Applied and Advanced Research, 33-36.

Rashid, S., \& Yadav, S. S. (2020). Impact of Covid-19 Pandemic on Higher Education and Research. Indian Journal of Human Development, 14(2), 340-343.

Roux, I. 1., \& Nagel, L. (2018). Seeking the best blend for deep learning in a flipped classroom - viewing student perceptions through the Community of Inquiry lens. International Journal of Educational Technology in Higher Education, 15(16), 128.

Slavin, E. (2011). Educational Psychology: Theory and Practice. Boston: Pearson.

Soudien, C. (2020). Complexities of difference and their significance for managing inequality in learning: Lessons from the COVID-19 crisis. Prospects, 49, 59-67.

Stone, B. B. (2012). Flip Your Classroom To Increase Active Learning And Student Engagement. Proceedings From 28th Annual Conference on Distance Teaching and Learning, (pp. 231-235). Madison.

Triana, D., Anggraito, Y. U., \& Ridlo, S. (2020). Effectiveness of Environmental Change Learning Tools Based on STEM-PjBL Towards 4C Skills of Students. Journal of Innovative Science Education, 9(2), 181-187.

Wang, K., \& Zhu, C. (2019). MOOC-based flipped learning in higher education: students' participation,experience and learning performance. International Journal of Educational Technology in Higher Education, 16(33), 1-18.

Wang, T. (2017). Overcoming barriers to 'flip': building teacher's capacity for the adoption of flipped classroom in Hong Kong secondary schools. Research and Practice in Technology Enhanced Learning, 12(6), 1-11. 